Nova Southeastern University

$1-1-2008$

\title{
Additional Records of Deep-Sea Fishes from Off Greater New England
}

\author{
Karsten E. Hartel \\ Harvard University \\ Christopher P. Kenaley \\ University of Washington - Seattle \\ John K. Galbraith \\ National Oceanic and Atmospheric Administration \\ Tracey Sutton \\ Virginia Institute of Marine Science, tsutton1@nova.edu \\ Find out more information about Nova Southeastern University and the Halmos College of Natural Sciences \\ and Oceanography.
}

Follow this and additional works at: https://nsuworks.nova.edu/occ_facarticles

Part of the Marine Biology Commons, and the Oceanography and Atmospheric Sciences and Meteorology Commons

\section{NSUWorks Citation}

Karsten E. Hartel, Christopher P. Kenaley, John K. Galbraith, and Tracey Sutton. 2008. Additional Records of Deep-Sea Fishes from Off Greater New England .Northeastern Naturalist, (3) : 317 -334. https://nsuworks.nova.edu/occ_facarticles/535.

This Article is brought to you for free and open access by the Department of Marine and Environmental Sciences at NSUWorks. It has been accepted for inclusion in Marine \& Environmental Sciences Faculty Articles by an authorized administrator of NSUWorks. For more information, please contact nsuworks@nova.edu. 
Additional Records of Deep-Sea Fishes from off Greater New England Author(s): Karsten E. Hartel, Christopher P. Kenaley, John K. Galbraith and Tracey T. Sutton Source: Northeastern Naturalist, Vol. 15, No. 3 (2008), pp. 317-334

Published by: Eagle Hill Institute

Stable URL: http://www.jstor.org/stable/25177116

Accessed: 27-05-2015 19:57 UTC

\section{REFERENCES}

Linked references are available on JSTOR for this article:

http://www.jstor.org/stable/25177116?seq=1\&cid=pdf-reference\#references_tab_contents

You may need to log in to JSTOR to access the linked references.

Your use of the JSTOR archive indicates your acceptance of the Terms \& Conditions of Use, available at http://www.jstor.org/page/ info/about/policies/terms.jsp

JSTOR is a not-for-profit service that helps scholars, researchers, and students discover, use, and build upon a wide range of content in a trusted digital archive. We use information technology and tools to increase productivity and facilitate new forms of scholarship. For more information about JSTOR, please contact support@jstor.org. 


\title{
Additional Records of Deep-sea Fishes from off Greater New England
}

\author{
Karsten E. Hartel ${ }^{1}$, Christopher P. Kenaley ${ }^{2, *}$, John K. Galbraith ${ }^{3}$, \\ and Tracey T. Sutton ${ }^{4}$
}

\begin{abstract}
A recent review of deep-sea fishes captured deeper than $200 \mathrm{~m}$ off greater New England, from the Scotian Shelf at $44^{\circ} \mathrm{N}$ to the southern New England Shelf at about $38^{\circ} \mathrm{N}$, documented 591 species. Subsequent trawling activity and reviews of deep-sea taxa occurring in the area have revealed that an additional 40 species inhabit the deep sea off New England. Thirty-two of these new records were captured in the course of 44 bottom trawls and 94 mid-water trawls over or in the proximity of Bear Seamount $\left(39^{\circ} 55^{\prime} \mathrm{N}, 67^{\circ} 30^{\prime} \mathrm{W}\right)$. Five of the 40 species have been described as new to science, at least in part from material taken in the study area. In addition to describing such information as specimen size and position, depth, and date of capture, errors made in the previous study of deep-sea fishes in the area are identified and corrected.
\end{abstract}

\section{Introduction}

A recent review of the deep-sea fish fauna found deeper than $200 \mathrm{~m}$ off greater New England documented 591 species (Moore et al. 2003). Since the Moore et al. manuscript was submitted in 2002, additional material from the area increases the knowledge of the fauna. Most of the new material is from US National Marine Fisheries Service (NMFS) cruises in the vicinity of Bear Seamount. This paper is a review of new records based largely on specimens collected during the DL03-04, DL04-08, DL04-09, DL05-06, and DL06-11 cruises of the R/V Delaware II. In addition, some errors in Moore et al. (2003) are corrected.

\section{Material and Methods}

We follow Moore et al. (2003) in the area of coverage, reporting on new records of species that typically reside below $200 \mathrm{~m}$ from the Scotian Shelf at $43^{\circ} \mathrm{N}$ to the Mid-Atlantic Bight at about $38^{\circ} \mathrm{N}$ and west of $63^{\circ} \mathrm{W}$. However, nearly all of the new records presented here were taken by the $\mathrm{R} / \mathrm{V}$ Delaware II during five exploratory cruises between 2003 and 2006, four or which concentrated activities in the vicinity of Bear Seamount $\left(39^{\circ} 55^{\prime} \mathrm{N}\right.$, $\left.67^{\circ} 30^{\prime} \mathrm{W}\right)$. The sampling consisted of 44 bottom trawls $(0-2151 \mathrm{~m})$ using

\footnotetext{
'Museum of Comparative Zoology, Harvard University, Cambridge, MA 02138. ${ }^{2}$ School of Aquatic and Fishery Sciences, College of Ocean and Fishery Sciences, University of Washington, Box 355020, Seattle, WA 98195. ${ }^{3}$ National Marine Fisheries Service, Woods Hole, MA 02543. ${ }^{4}$ Virginia Institute of Marine Sciences, PO Box 1346, Gloucester Point, VA 23062. “Corresponding author - ckenaley@u. washington.edu.
} 
a Yankee 36 otter trawl and 94 mid-water trawls (0-2208 m) using an International Young Gadoid Pelagic Trawl (IYGPT; Table 1). In this update, we include only those species for which there are new records captured in the study area or clarifications of earlier records published in Moore et al. (2003). Additional records of various rare species that have been previously reported are available online at http://collections.oeb.harvard.edu/Fish/ FishSearch.htm. Common names not given in either this report or in Moore et al. (2003) are available in the Integrated Taxonomic Information System database (http://www.itis.usda.gov).

The majority of the studied material is deposited at the Museum of Comparative Zoology (MCZ), Harvard University, with some additional material at the National Museum of Natural History (USNM), Smithsonian Institution. Each specimen citation is followed by standard length in millimeters (unless total length [TL] is given), capture latitude and longitude, depth in meters, and date. Where specific capture depth was not available, meters of wire out (mwo) are given. Expanded specimen information such as vessel, station, and preservation status may be retrieved from corresponding museum catalogs available via the internet. Museum abbreviations follow Leviton et al. (1985).

\section{Results and Discussion}

This review shows that 631 species are now confirmed to inhabit the area at depths below $200 \mathrm{~m}$ : the 591 species reported by Moore et al. (2003) in addition to those 40 species reported here. The latter number excludes three species: Apristurus melanoasper Iglésias, Nakaya, and Stehmann, Photostomias goodyeari Kenaley and Hartel, and Pseudoscopelus astronesthidens Prokofiev and Kukuev, species recently described but reported by Moore et al. (2003) as undescribed species. Similar to the faunal analysis of Moore et al. (2003), 19 of these 40 new records are northward extensions of typically tropical species, most likely individuals following or being carried by the warm waters of the Gulf Stream. Twelve are westward extensions of species previously known only from more easterly longitudes. None of the records reported here represent species with typically more northerly ranges. Reflecting the

Table 1 . Summary of trawling activity made by the NOAA ship R/V Delaware II since the submission in 2002 of Moore et al. (2003). mwo = meters of wire out, actual depth not recorded.

\begin{tabular}{lccccccc} 
& \multicolumn{3}{c}{ Mid-water trawls } & & \multicolumn{3}{c}{ Benthic trawls } \\
\cline { 2 - 4 } \cline { 6 - 8 } Cruise & Number & $\begin{array}{c}\text { Maximum } \\
\text { depth }(\mathrm{m})\end{array}$ & $\begin{array}{c}\text { New } \\
\text { records }\end{array}$ & & Number & $\begin{array}{c}\text { Maximum } \\
\text { depth }(\mathrm{m})\end{array}$ & $\begin{array}{c}\text { New } \\
\text { records }\end{array}$ \\
\hline DL03-04 & 22 & 1779 & 8 & & 12 & 2027 & 3 \\
DL04-08 & 18 & 1200 mwo & 0 & & 14 & 2200 mwo & 1 \\
DL04-09 & 16 & 1807 & 10 & & 10 & 2095 & 0 \\
DL05-06 & 19 & 1620 & 6 & & 8 & 2151 & 0 \\
DL06-11 & 19 & 2208 & 4 & & 0 & - & 0 \\
Total/max & 94 & 2208 & 28 & 44 & 2151 & 4 \\
\hline
\end{tabular}


sampling effort at the heart of this study, 32 of the new records were captured over or in the proximity of Bear Seamount (Table 1). Additionally, eight of the species reported here have been described as new to science between 2002 and 2005. The continued description of undocumented and new species from the area is strong evidence that a considerable number of species awaits discovery in the deep waters off greater New England.

\section{Annotated List Of New Records}

\section{Carcharhiniformes}

\section{Scyliorhinidae - Deep-water catsharks}

Apristurus melanoasper Iglésias, Nakaya, and Stehmann, 2004 - Benthopelagic, 512-1520 m on the North Atlantic slope off northern United States, France, Ireland, and the British Isles (Iglésias et al. 2004). This recently described species was listed as Apristurus sp. by Moore et al. (2003) and was described, in part, from a mature male taken in the area (MCZ 125408, 692 $\mathrm{mm}$ TL, paratype, $\left.39^{\circ} 17^{\prime} \mathrm{N}, 72^{\circ} 11^{\prime} \mathrm{W}, 512-662 \mathrm{~m}\right)$. An additional 15 specimens $(200-692 \mathrm{~mm} \mathrm{TL})$ are known from the same general area $\left(37^{\circ}-40^{\circ} \mathrm{N}\right.$, $67^{\circ}-74^{\circ} \mathrm{W}$ at $\left.512-1830 \mathrm{~m}\right)$ : MCZ 125407, 132498-499, 132509, 137071, $137073,137078,138052,138754,147899,155425-427$, and 165114.

\section{Albuliformes}

\section{Notacanthidae - Spiny eels}

Notacanthus bonapartei Risso, 1840 - Benthopelagic at bathyal depths and previously known only from the eastern Atlantic and the Mediterranean Sea (Sulak 1990). Two specimens (MCZ 163098, 1:304 mm; and MCZ 163360, 1:410 mm) taken at one station on Bear Seamount $\left(39^{\circ} 55^{\prime} \mathrm{N}\right.$, $67^{\circ} 24^{\prime} \mathrm{W}, 0-1888 \mathrm{~m}, 19$ May 2003) have proven to be this species and are the first records for the western Atlantic. In 2004, an additional small specimen (MCZ 164491, 1:151 mm) was taken from the same area.

\section{Anguilliformes}

\section{Family Incerta Sedis - An unassigned larval eel}

Ascomana eximia Castle, 1967 - Rare. Known in the eastern Atlantic from the Cape Verde Islands to South Africa and in the western North Atlantic from the Caribbean Sea (Castle 1967, Smith 1989a). This species is based on the larval form, and to date, it has not been linked to an adult. Tentatively assigned to Coloconger (Smith 1989a), this assignment is thought to be doubtful (D.G. Smith, USNM, Washington, DC, pers. comm. 2006). A specimen $\left(\mathrm{MCZ} 165874,1: 165 \mathrm{~mm}\right.$ TL, 39 $50^{\circ} \mathrm{N}, 67^{\circ} 26^{\prime} \mathrm{W}$ ) is an area record.

\section{Saccopharyngiformes}

\section{Cyematidae - Bobtail eels}

Cyema atrum Günther, 1878 - Meso- to bathypelagic at 300-3000 m, circumglobal (Smith 1989b). Two specimens (MCZ 163291, 1:116 mm, 
$39^{\circ} 49^{\prime} \mathrm{N}, 67^{\circ} 27^{\prime} \mathrm{W}, 3500$ mwo, 15 May 2003; and MCZ 165935, 1 gravid female: $138 \mathrm{~mm}, 39^{\circ} 47^{\prime} \mathrm{N}, 67^{\circ} 33^{\prime} \mathrm{W}, 0-2205 \mathrm{~m}, 16$ June 2006) taken over Bear Seamount represent the first records of this species in the study area.

Neocyema sp. (Fig. 1) - The only known species of this genus, N. erythrosoma, found at bathypelagic depths in the eastern central and eastern South Atlantic, is previously known from only the two type specimens captured at 2100-2300 $\mathrm{m}$ (Castle 1978). A single specimen assigned to this genus (MCZ $165900,1: 91 \mathrm{~mm}, 39^{\circ} 51^{\prime} \mathrm{N}, 67^{\circ} 02^{\prime} \mathrm{W}, 17$ June 2006 ) was taken between the surface and $2284 \mathrm{~m}$ over Bear Seamount. MCZ 165900 represents the third known specimen of this monotypic genus and is the first record for the North Atlantic. Shannon DeVaney (KU) and the senior author continue evaluating the specific identity of this specimen.

\section{Monognathidae - One-jawed eels}

Monagnathus jesperseni (Bertin, 1936) (Fig. 2) - Bathypelagic in the eastern North Atlantic; previously known from only two specimens, one

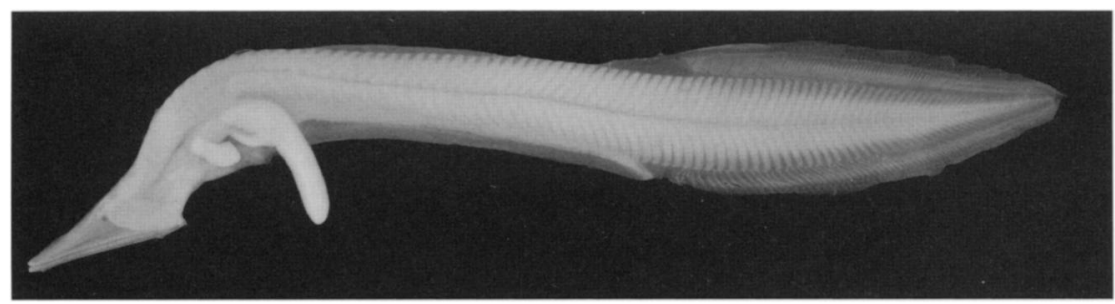

Figure 1. Neocyema sp., MCZ 165900, $91 \mathrm{~mm} \mathrm{SL}, 39^{\circ} 51^{\prime} \mathrm{N}, 67^{\circ} 02^{\prime} \mathrm{W}, 0-2284 \mathrm{~m}$.

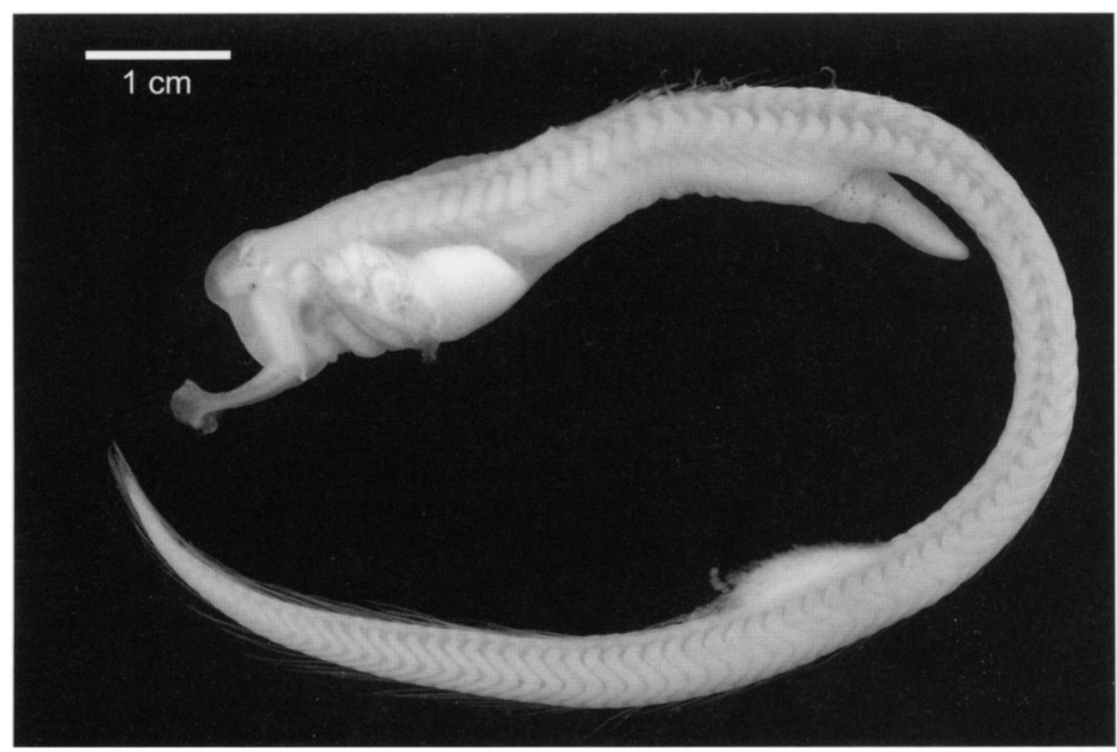

Figure 2. Monagnathus jesperseni, $\mathrm{MCZ} 164702,142 \mathrm{~mm} \mathrm{SL}, 39^{\circ} 50^{\prime} \mathrm{N}, 67^{\circ} 26^{\prime} \mathrm{W}$, 0-1592 m. 
of which was collected at a discrete depth between $2100-2300 \mathrm{~m}$ at approximately $3000 \mathrm{~m}$ above the bottom (Bertelsen and Nielsen 1987). A single specimen (MCZ 164702, 1:142 mm) was taken near Bear Seamount $\left(39^{\circ} 50^{\prime} \mathrm{N}, 67^{\circ} 26^{\prime} \mathrm{W}, 0-1592 \mathrm{~m}, 18\right.$ May 2005$)$ by a NMFS cruise. This specimen represents the third known specimen of the species and the first record from the western Atlantic Ocean.

\section{Osmeriformes}

\section{Opisthoproctidae - Barreleyes}

Rhynchohyalus natalensis (Gilchrist and von Bonde, 1924) (Fig. 3) - Mesopelagic at 250 to $625 \mathrm{~m}$ in the North Atlantic based on MCZ records; probably circumtropical (Cohen 1984). A single specimen (MCZ 164701, 1:70 mm, $39^{\circ} 50^{\prime} \mathrm{N}, 67^{\circ} 26^{\prime} \mathrm{W}, 12$ April 2005) from near Bear Seamount is the first adult taken north of Bermuda. Larval waifs (MCZ 60718, 65994), carried north on the Gulf Stream, have been taken at $39^{\circ}$ and $36^{\circ} \mathrm{N}$, respectively.

\section{Alepocephalidae - Slickheads}

Einara edentula (Alcock, 1892) - Meso- to bathypelagic, 700-2000 m, known from the North Atlantic, eastern and western tropical Pacific, and Indian oceans (Markle and Sazonov 1990). A record, recently identified and brought to our attention by D. Markle (OS, Corvallis, OR, pers. comm. 2006), adds this species to the area. The specimen (MCZ 49348, 1:136 mm) was collected by William Schroeder at $42^{\circ} 39^{\prime} \mathrm{N}, 63^{\circ} 58^{\prime} \mathrm{W}$ in an otter trawl fished from the surface to $935 \mathrm{~m}, 26$ July 1952.

Einara macrolepis (Koeford, 1927) - Bathy- or benthopelagic in the eastern and western Atlantic, eastern Pacific, and Indian oceans (Markle and Sazonov 1990). Specimens taken in bottom trawls fished open on NMFS cruises in the vicinity of Bear Seamount in 2003 and 2004 represent the first records for the area $\left(\mathrm{MCZ} 163139,1: 65 \mathrm{~mm}, 39^{\circ} 49^{\prime} \mathrm{N}, 67^{\circ} 24^{\prime} \mathrm{W}, 3000 \mathrm{mwo}\right.$, 16 May 2003; and MCZ 164144, 1:164 mm, 39 $49^{\circ} \mathrm{N}, 67^{\circ} 24^{\prime} \mathrm{W}, 0-1636 \mathrm{~m}$, 6 June 2004). An additional specimen (MCZ 164437, 1:105 mm, 31 ${ }^{\circ} 20^{\prime} \mathrm{N}$, $76^{\circ} 20^{\prime} \mathrm{W}, 10$ February 1978 ) was collected south of the area in a mid-water trawl fished between the surface and $1480 \mathrm{~m}$.

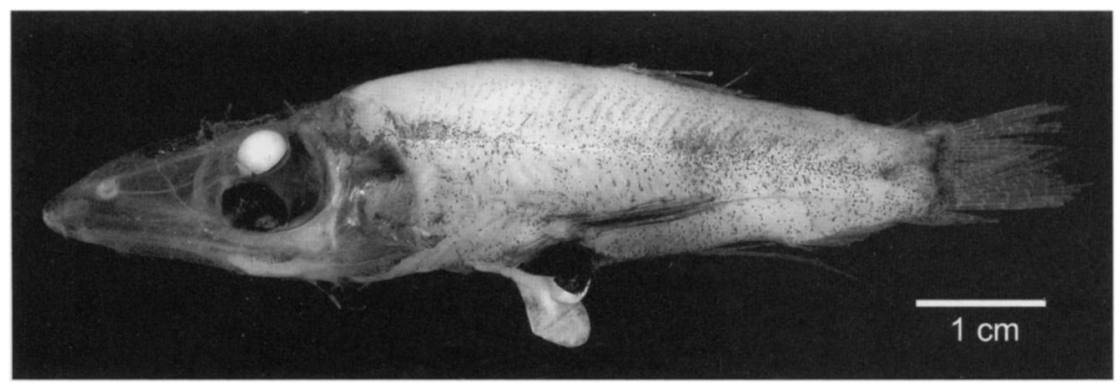

Figure 3. Rhynchohyalus natalensis, MCZ 164701, $70 \mathrm{~mm} \mathrm{SL}, 39^{\circ} 50^{\prime} \mathrm{N}, 67^{\circ} 26^{\prime} \mathrm{W}$. 


\section{Platytroctidae - Tubeshoulders}

Platytroctes apus Günther, 1878 (Fig. 4) - Bathypelagic, 1000-2000 m, in the tropical western Atlantic, Indian, and Pacific oceans and in the eastern Atlantic from Iceland to south of the equator at the Sierra Leone Rise (Pakhorukov 1999, Quero et al. 1990). A single specimen (MCZ 163133, 1:97 $\mathrm{mm}, 39^{\circ} 52^{\prime} \mathrm{N}, 67^{\circ} 15^{\prime} \mathrm{W}, 3000$ mwo, 15 May 2003) taken in a bottom trawl fished open by NMFS cruises over Bear Seamount in 2003 represents the first record in the area.

\section{Stomiiformes}

\section{STOMIIDAE - Dragonfishes}

\section{Astronesthinae - Snaggletooth dragonfishes}

Astronesthes gudrunae Parin and Borodulina, 2002 - Mesopelagic, known only in the Atlantic from equatorial waters north to off Hudson Canyon (MCZ 101356, 1:77 mm, 38 $20^{\prime} \mathrm{N}, 75^{\circ} 05^{\prime} \mathrm{W}, 200-0 \mathrm{~m}, 23$ July 1993). This recently described species was described in a recent review of the $A$. niger-species group by Parin and Borodulina (2002).

Rhadinesthes decimus (Zugmayer, 1911) - Mesopelagic, previously known from over 30 records off Greenland to $27^{\circ} \mathrm{S}$ in the eastern Atlantic and elsewhere in the tropical Indian and Pacific oceans (Gibbs 1984). A single large specimen of $R$. decimus taken over Bear Seamount (MCZ 164113, 1:365 $\mathrm{mm}, 39^{\circ} 58^{\prime} \mathrm{N}, 67^{\circ} 23^{\prime} \mathrm{W}, 0-1640 \mathrm{~m}, 5 \mathrm{June} 2004$ ) is the first area record and the first capture of this species in the western Atlantic south of Greenland.

\section{Melanostomiinae - Black dragonfishes}

Eustomias bigelowi Welsh, 1923 - Mesopelagic, widely distributed, known from $20-35^{\circ} \mathrm{N}$ and $0-25^{\circ} \mathrm{S}$ in the Atlantic (Clarke 2000, McEachran and Fechhelm 1998). A specimen from the vicinity of Bear Seamount is a new record for the area (MCZ 165944, 1:141 mm, 39 $511^{\prime} \mathrm{N}$, $66^{\circ} 55^{\prime} \mathrm{W}, 0-653 \mathrm{~m}, 18$ June 2006 ).

Eustomias contiguus Gomon and Gibbs, 1985 - Mesopelagic, previously known from the tropical and subtropical North Atlantic at 0-1835 m, including a single specimen (USNM 222570) taken southeast of Cape Hatteras

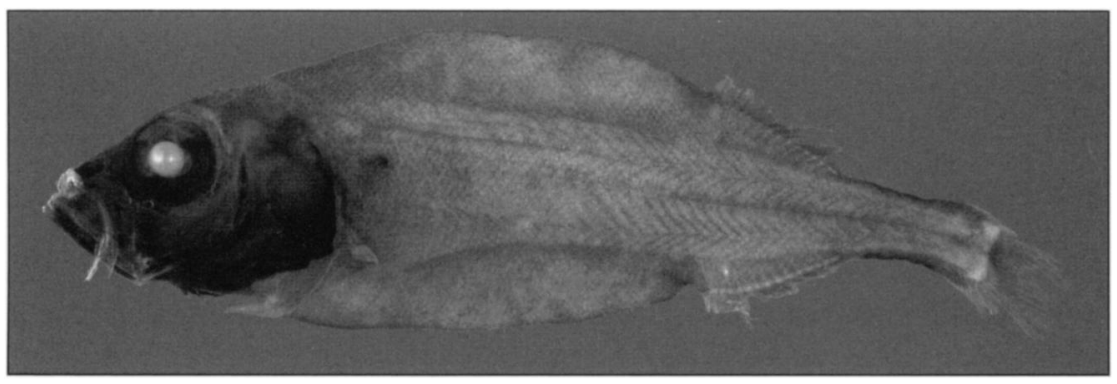

Figure 4. Platytroctes apus, MCZ 163133, $101 \mathrm{~mm} \mathrm{SL}, 3^{\circ} 52^{\prime} \mathrm{N}, 67^{\circ} 15^{\prime} \mathrm{W}, 3000 \mathrm{mwo}$. 
(Gomon and Gibbs 1985). MCZ $165940\left(1: 126 \mathrm{~mm}, 39^{\circ} 55^{\prime} \mathrm{N}, 67^{\circ} 32^{\prime} \mathrm{W}\right.$, 0-503 m, 17 June 2006) represents a northern range extension for this species and new area record.

Eustomias jimcraddocki Sutton and Hartel, 2004 (Fig. 5) - Mesopelagic, at depths of $0-1931 \mathrm{~m}$ in the western North Atlantic from $40^{\circ} 20^{\prime} \mathrm{N}, 66^{\circ} 41^{\prime} \mathrm{W}$ to the north Sargasso Sea at $26^{\circ} 35^{\prime} \mathrm{N}$ (Sutton and Hartel 2004). This recently described species is now known from 15 specimens, five of which were captured in the area: MCZ 82661 (1:126 mm), MCZ 162851 (1:141 mm), MCZ 162290 (1:143 mm), MCZ 163108 (1:161 mm), and USNM 323066(1:124 mm).

Eustomias furcifer Regan and Trewavas, 1930 (Fig. 6) - Rare at mesopelagic depths, but widely distributed in the Atlantic and also known from the Indian and Pacific oceans (Gibbs and Barnett 1990, Morrow and Gibbs 1964). A single specimen (MCZ 164706, 1:120 mm, 39 $50^{\prime} \mathrm{N}, 67^{\circ} 26^{\prime} \mathrm{W}, 18$ April 2005) taken near Bear Seamount is the first area record.

Eustomias polyaster Parr, 1927 - Mesopelagic, at depths of 0-1500 m in the tropical and subtropical western Atlantic (Gomon and Gibbs 1985, McEachran and Fechhelm 1998). A single specimen (MCZ 163116, 1:185 $\mathrm{mm}, 39^{\circ} 54^{\prime} \mathrm{N}, 67^{\circ} 26^{\prime} \mathrm{W}, 1000$ mwo, 16 May 2003) captured near Bear Seamount is the first area record.

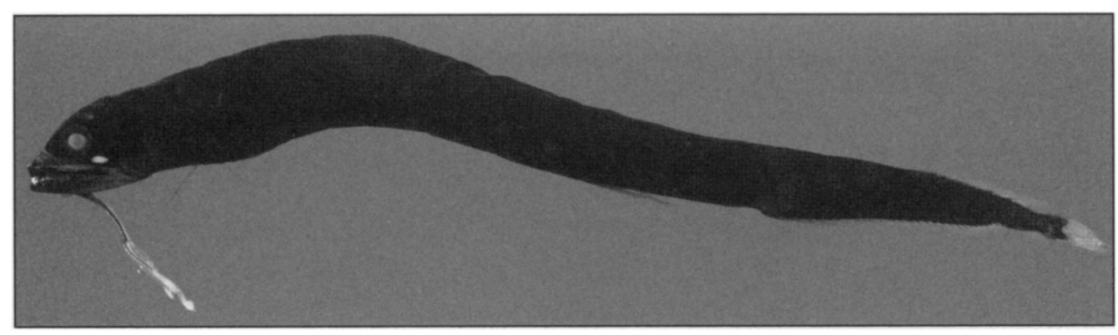

Figure 5. Eustomias jimcraddocki, MCZ 162290, $144 \mathrm{~mm} \mathrm{SL}, 40^{\circ} 22^{\prime} \mathrm{N}, 66^{\circ} 44^{\prime} \mathrm{W}$, 0-809 m.

Figure 6. Eustomias furcifer, MCZ 164706, 120 $\mathrm{mm} \mathrm{SL}, 39^{\circ} 50^{\prime} \mathrm{N}, 67^{\circ} 26^{\prime} \mathrm{W}$, $0-1592 \mathrm{~m}$.

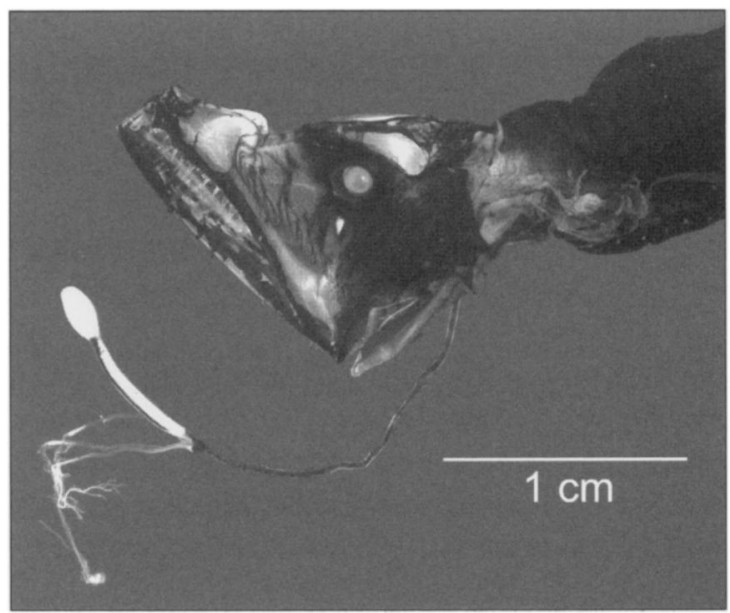


Melanostomias margaritifer Regan and Trewavas, 1930 - Mesopelagic, previously known from the tropical western Atlantic off Puerto Rico, and Jamaica, and in the Gulf of Mexico (McEachran and Fechhelm 1998). A single specimen captured during cruise DL03-04 (MCZ 163251, 1:90 mm, 39 $54^{\prime} \mathrm{N}$, $67^{\circ} 26^{\prime} \mathrm{W}, 1000 \mathrm{mwo}, 16$ May 2003) is the first record of this species for the area.

\section{Malacosteinae - Loosejaw dragonfishes}

Photostomias atrox (Alcock, 1890) - Mesopelagic, previously considered endemic to the Indian Ocean, now understood to be cosmopolitan in subtropical and tropical waters (Kenaley and Hartel 2005). A single specimen (MCZ 131425, 1:96 mm, 38 ${ }^{\circ} 58^{\prime} \mathrm{N}, 68^{\circ} 18^{\prime} \mathrm{W}, 400-299 \mathrm{~m}, 15$ October 1982) was taken in the area.

Photostomias goodyeari Kenaley and Hartel, 2005 (Fig. 7) - Mesopelagic, from $60 \mathrm{~m}$ during the day to greater than $1050 \mathrm{~m}$ at night in the western North Atlantic (Kenaley, in press); restricted to the temperate and tropical North Atlantic (Kenaley and Hartel 2005). This recently described species is now known from over 50 specimens in the study area.

\section{Aulopiformes}

\section{Giganturidae - Telescopefishes}

Gigantura chuni Brauer, 1901 - Meso-to bathypelagic (usually 500-1300 $\mathrm{m}$ ) in tropical waters worldwide (Johnson and Bertelsen 1991). Two specimens (MCZ 164306, 1:110 mm, 39 $55^{\circ} \mathrm{N}, 67^{\circ} 19^{\prime} \mathrm{W}, 0-1082 \mathrm{~m}$, 5 June 2004; and MCZ 165926, 1:119 mm, 40 $05^{\circ} \mathrm{N}, 67^{\circ} 57^{\prime} \mathrm{W}, 0-1011 \mathrm{~m}, 14$ June 2006) taken at Bear Seamount are the first known records north of about $30^{\circ} \mathrm{N}$ and are new area records.

\section{Scopelarchidae - Pearleyes}

Benthalbella infans Zugmayer, 1911 - Meso- to bathypelagic, 300-600 m in tropical and subtropical waters of the Atlantic, Pacific, and Indian oceans; absent from the tropical eastern Atlantic (Johnson 1974). A single specimen (MCZ 164233, 1:86 mm, 39 55' $\mathrm{N}, 67^{\circ} 19^{\prime} \mathrm{W}, 0-1082 \mathrm{~m}, 5$ June 2004) taken over Bear Seamount extends the range north and west into the study area.

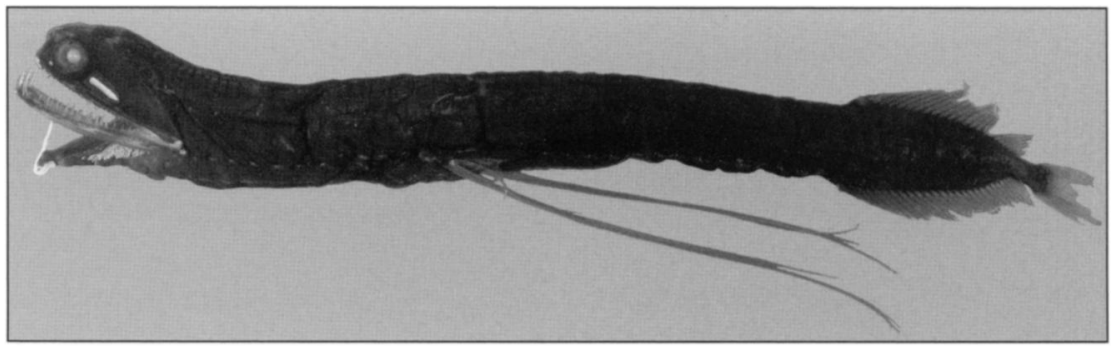

Figure 7. Photostomias goodyeari, $\mathrm{MCZ} 100833,174 \mathrm{~mm} \mathrm{SL}, 32^{\circ} 04^{\prime} \mathrm{N}, 64^{\circ} 03^{\prime} \mathrm{W}$, 978-800m. 


\section{Lophiiformes}

\section{Himantolophidae - Footballfishes}

Himantolophus brevirostris-species group - Mesopelagic, previously known from specimens taken in the tropical and eastern North Atlantic and from scattered records in the eastern Indian Ocean, South Pacific, and Indonesian waters (Bertelsen and Krefft 1988). Males of the Himantolophidae can be identified to species groups only; those of the $H$. brevirostris-species group most likely represent male counterparts of the female $H$. groenlandicus-species group (Bertelsen and Krefft 1988). MCZ 164737 (1 male:29 $\mathrm{mm}, 39^{\circ} 54^{\prime} \mathrm{N}, 67^{\circ} 19^{\prime} \mathrm{W}, 0-1595 \mathrm{~m}, 14$ April 2006) represents the first record of this species group in the study area. However, because this group likely represents males of the $H$. groenlandicus group, this specimen may represent $H$. groenlandicus, the most common and widely distributed member of the group (Bertelsen and Krefft 1988).

\section{Oneirodidae - Dreamers}

Dolopichthys danae Regan, 1926 (Fig. 8) - Meso-to bathypelagic, tropical to temperate eastern North Atlantic (Pietsch 1972). A single female (MCZ 164089, 1:109 mm, 3950'N, 67²6'W, 0-1648 m, 6 June 2004) taken over Bear Seamount is the first record for the western North Atlantic.

Dolopichthys longicornis Parr, 1927 - Meso- to bathypelagic, sparsely distributed in tropical and subtropical waters of all oceans (Pietsch 1972). Although several specimens have been captured off Bermuda, a single female taken during the DL03-04 cruise is the first area record (MCZ 162989, $1: 52 \mathrm{~mm}, 39^{\circ} 54^{\prime} \mathrm{N}, 67^{\circ} 33^{\prime} \mathrm{W}, 3500 \mathrm{mwo}, 16$ May 2003$)$.

Oneirodes epithales Orr, 1991 - This species, first described in 1991 from a single specimen taken $720 \mathrm{~km}$ south of Newfoundland $\left(41^{\circ} 06^{\prime} \mathrm{N}\right.$,

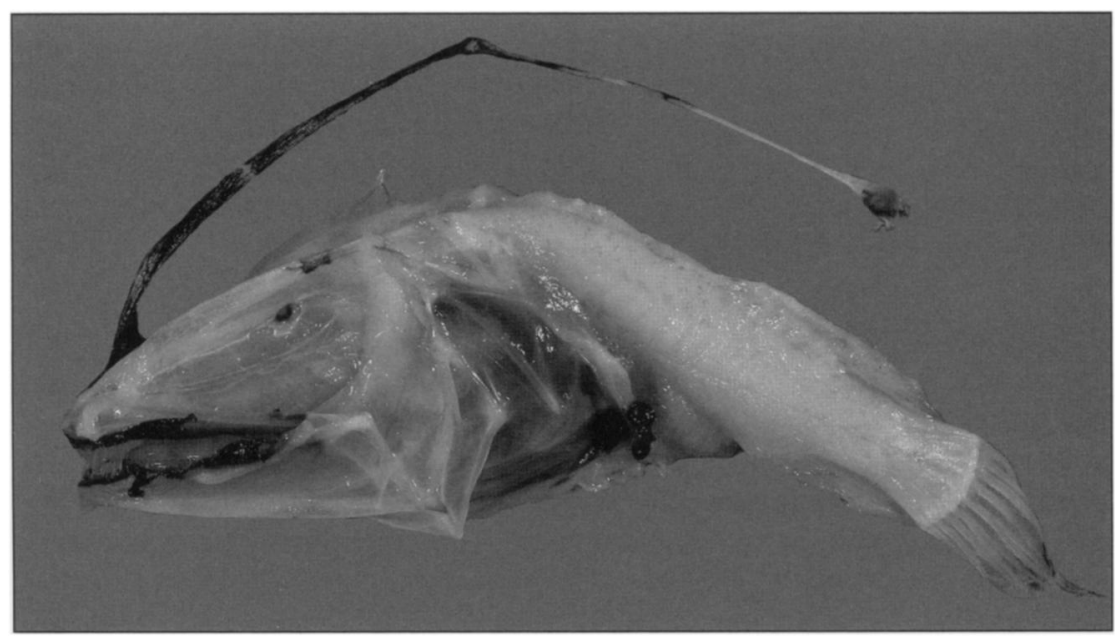

Figure 8. Dolopichthys danae, MCZ 164089, $109 \mathrm{~mm} \mathrm{SL}, 39^{\circ} 50^{\prime} \mathrm{N}, 67^{\circ} 26^{\prime} \mathrm{W}$, $0-1648 \mathrm{~m}$. 
$56^{\circ} 26^{\prime \prime} \mathrm{W}, 0-1829 \mathrm{~m}$ ), was not included in Moore et al. (2003). A second specimen from the area was collected near Bear Seamount on 12 April 2005 (MCZ 164733, 1:46 mm, 3950'N, 67²6' W, depth unknown).

Oneirodes posti Bertelsen and Grobecker, 1980 - Meso- to bathypelagic, 0-1800 m, previously known from only two type specimens captured off the Azores and in the subarctic Atlantic (Bertelsen and Grobecker 1980). A third female, and largest known specimen, collected in the area extends the range considerably west (MCZ 162998, 1:135 mm, 39 ${ }^{\circ} 56^{\prime} \mathrm{N}, 67^{\circ} 36^{\prime} \mathrm{W}, 4000 \mathrm{mwo}$, 18 May 2003).

Phyllorhinichthys balushkini Pietsch, 2004 - Meso-to bathypelagic, 0-3200 $\mathrm{m}$, known previously from six specimens captured in the eastern and western Atlantic between $64^{\circ} \mathrm{N}$ and $33^{\circ} \mathrm{S}$ (Pietsch 2004). The seventh known specimen (MCZ 164228, 1:125 mm, 39 $50^{\prime} \mathrm{N}, 67^{\circ} 28^{\prime} \mathrm{W}, 0-1636 \mathrm{~m}, 6$ June 2004) was captured over Bear Seamount while the description of this species was in press.

\section{Gigantactinidae - Whipnose anglerfishes}

Gigantactis gibbsi Bertelsen, Pietsch and Lavenberg, 1981 - Meso- to bathypelagic, 465-1000 m, previously known from only two specimens from the Gulf of Guinea and off Bermuda (Bertelsen et al. 1981). One female (MCZ 164218, 1:114 mm, 39 $58^{\prime} \mathrm{N}, 67^{\circ} 23^{\prime} \mathrm{W}, 0-1640 \mathrm{~m}, 5$ June 2004) taken over Bear Seamount is the first record for the area.

Gigantactis ios Bertelsen, Pietsch and Lavenberg, 1981 (Fig. 9) - Mesoto bathypelagic, previously know from only four females captured in the eastern Atlantic (T.W. Pietsch, University of Washington, Seattle, WA, pers. comm. 2004). This new area record is based on a single female (MCZ $163303,1: 225 \mathrm{~mm}, 39^{\circ} 55^{\prime} \mathrm{N}, 67^{\circ} 24^{\prime} \mathrm{W}, 0-1888 \mathrm{~m}, 19$ May 2003) taken over Bear Seamount.

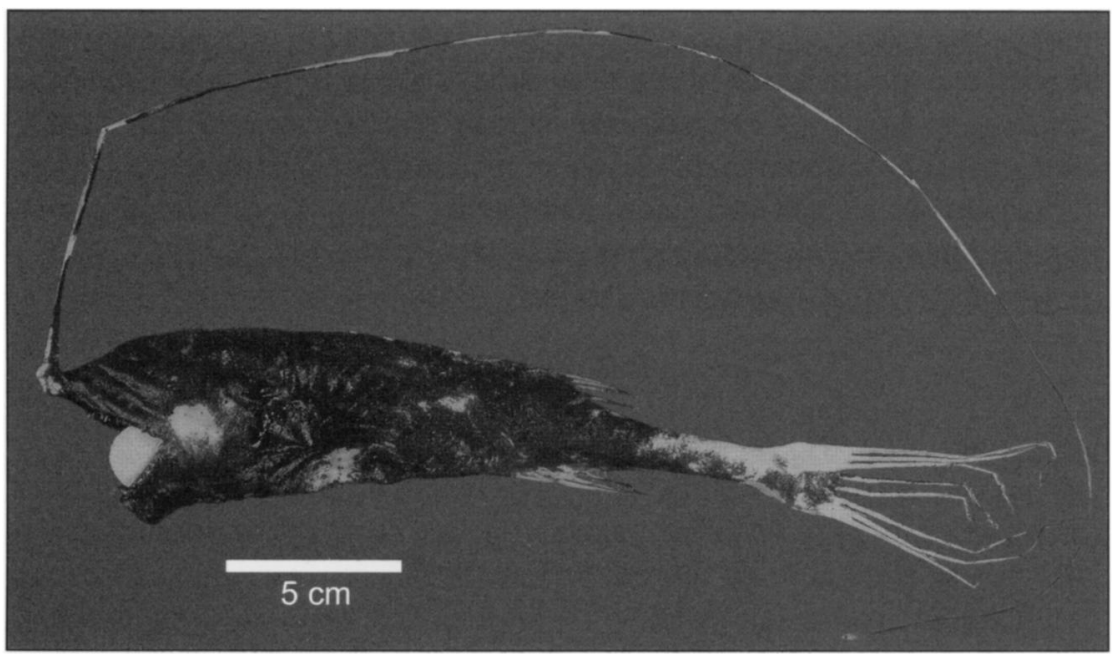

Figure 9. Gigantactis ios, MCZ 163303, $225 \mathrm{~mm} \mathrm{SL}, 39^{\circ} 55^{\prime} \mathrm{N}, 67^{\circ} 24^{\prime} \mathrm{W}, 0-1888 \mathrm{~m}$. 


\section{Linophrynidae - Leftvent seadevils}

Linophryne brevibarbata Beebe, 1932 - Bathypelagic, previously known from only five females and two parasitic males from the tropical and subtropical North Atlantic at 0-1700 m (Bertelsen 1980). Two additional specimens and new records for the area were captured during the DL04-09 cruise over Bear Seamount (MCZ 164211, 1:33 mm, 39 $52^{\prime} \mathrm{N}$, $67^{\circ} 27^{\prime} \mathrm{W}, 0-1324 \mathrm{~m}, 3$ June 2004; $\mathrm{MCZ} 164212,1: 30 \mathrm{~mm}, 39^{\circ} 55^{\prime} \mathrm{N}$, $67^{\circ} 23^{\prime} \mathrm{W}, 0-779 \mathrm{~m}, 4$ June 2004).

Linophryne coronata Parr, 1927 - Bathypelagic, known from 12 females and two parasitic males in the western North Atlantic and eastern North $\mathrm{Pa}$ cific from 0-3000 m (Bertelsen 1982). A single female of this species is the first capture for the area (MCZ 162991, 1:35 mm, 39 $57^{\prime} \mathrm{N}, 67^{\circ} 47^{\prime} \mathrm{W}$, depth unknown, 14 May 2003).

Linophryne macrodon Regan, 1925 - Bathypelagic, 300-1300 m, previously known from only six females and one attached male from the western North Atlantic and the Gulf of Panama (Bertelsen 1982). A seventh specimen, taken over Bear Seamount, is the first record of this species for the area (MCZ 164217, 1:39 mm, 3952'N, 67²2' W, 0-1324 m, 3 June 2003).

\section{Gadiformes}

\section{MERLUCCIIDAE - Merlucciid hakes}

Steindachneriinae - Luminous hakes

Steindachneria argentea Goode and Bean, 1896 (Fig. 10) - Bathydemersal at $400-500 \mathrm{~m}$, previously known in the western Atlantic from $9-30^{\circ} \mathrm{N}$ (Cohen et al. 1990). This species was omitted from Moore et al. (2003) having been caught just south of the study area at $35^{\circ} 51^{\prime} \mathrm{N}, 74^{\circ} 51^{\prime} \mathrm{W}$; however, a single specimen (MCZ 166402, 1:283 mm) captured by F/V Perception in southern Hudson Canyon in 2006 confirms the occurrence of this species in deep water off the New England region.

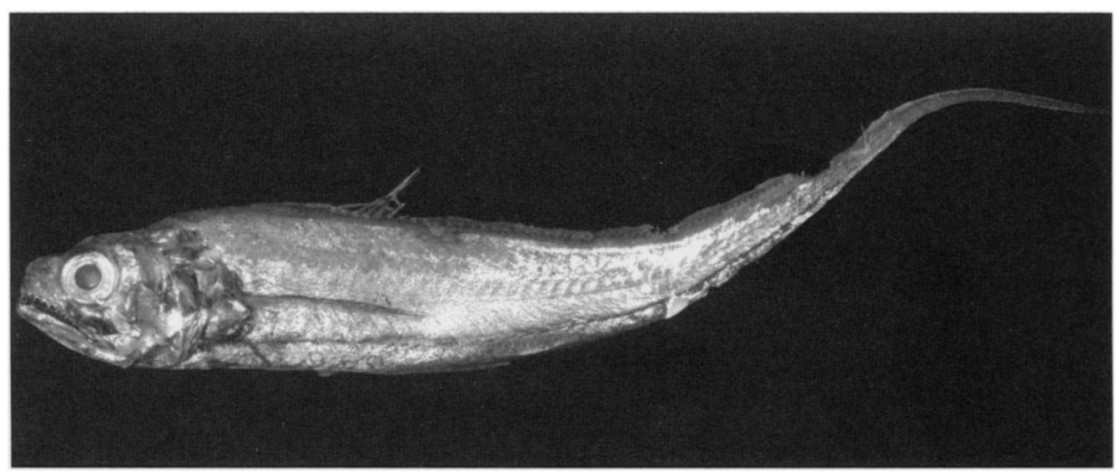

Figure 10. Steindachneria argentea. MCZ 166402, $283 \mathrm{~mm}$ TL, southern Hudson Canyon, $0-183 \mathrm{~m}$. 


\section{Ophidiiformes}

\section{Ophidiidae - Cusk eels}

Lamprogrammus shcherbachevi Cohen and Rohr, 1933 (Fig. 11) - Benthopelagic, to about $1000 \mathrm{~m}$; previously known from scattered records off Chile, the northwest coast of Australia, Angola, the northeast coast of South America, and the Faroe Islands (Nielsen et al. 1999). A large exterilium larva was collected near Bear Seamount in 2006. Meristic data suggest that it is this species (J.G. Nielsen, Zoological Museum, University of Copenhagen [ZMUC], Copenhagen, Denmark, pers. comm. 2006). MCZ 165928 (1:110 $\mathrm{mm}, 39^{\circ} 55^{\prime} \mathrm{N}, 67^{\circ} 32^{\prime} \mathrm{W}, 0-503,17$ June 2006 ) is the first record of this species in the study area.

\section{Stephanoberyciformes}

\section{Cetomimidae - Whalefishes}

Rhamphocetichthys cf. savagei Paxton, 1898 (Fig. 12) - Probably bathypelagic, previously known from four specimens captured in open nets fished between 1000 and $2100 \mathrm{~m}$ in the Coral Sea, Gulf of California, and central Atlantic (Paxton 1989). A single specimen (MCZ 163187, 1:111 mm, 3948' N,

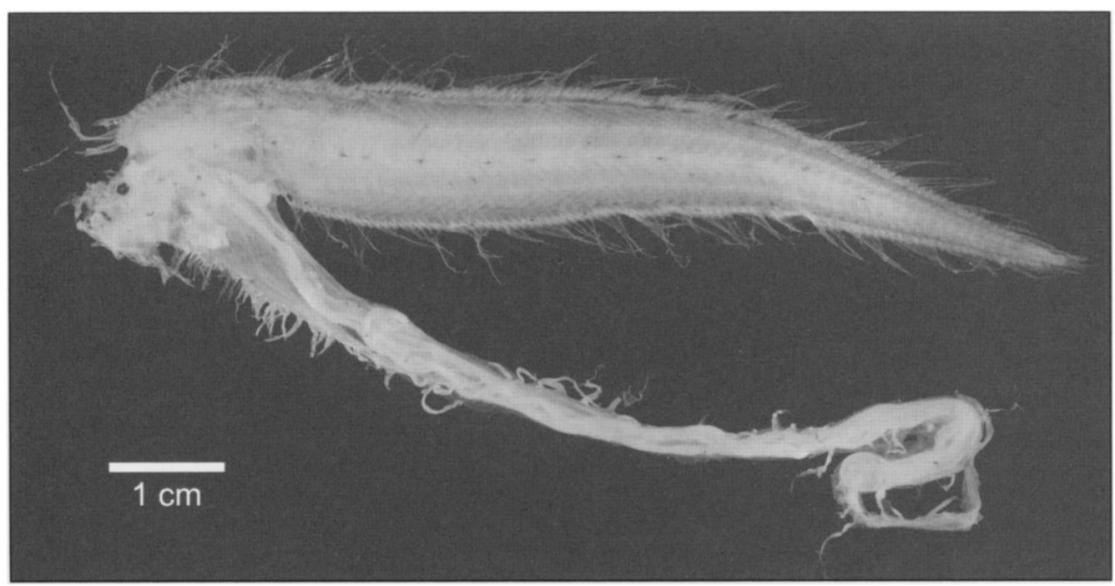

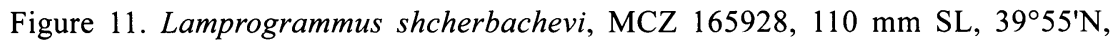
$67^{\circ} 32^{\prime} \mathrm{W}, 0-503 \mathrm{~m}$.

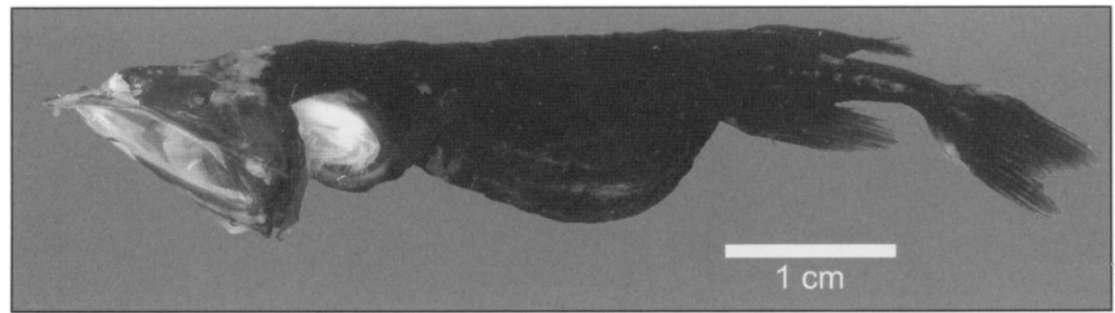

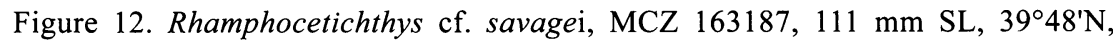
$67^{\circ} 22^{\prime} \mathrm{W}, 0-1324 \mathrm{~m}$. 
$67^{\circ} 22^{\prime} \mathrm{W}, 4000$ mwo, 18 May 2003) collected near Bear Seamount belongs to Rhamphocetichthys and is the second known Atlantic specimen of the genus. Its specific status, however, is uncertain due to the poor condition of comparative material (J. Paxton, Australian Museum [AMS], Sydney, NSW, Australia, pers. comm. 2003).

\section{Scorpaeniformes}

\section{Liparidae - Snailfishes}

Paraliparis hystrix Merrett, 1893 (Fig. 13) - Meso- or benthopelagic, previously known only from the eastern Atlantic (N. Chernova, Zoological Institute [ZIN], St. Petersburg, Russia, pers. comm. 2004). Several specimens (MCZ 155473, 1:137 mm, 38 ${ }^{\circ} 11^{\prime} \mathrm{N}, 73^{\circ} 38^{\prime} \mathrm{W}, 0-682 \mathrm{~m}, 16 \mathrm{Feb} 1999$; ISH $3430-1979,1: 104 \mathrm{~mm}, 39^{\circ} 50^{\prime} \mathrm{N}, 70^{\circ} 55^{\prime} \mathrm{W}, 1004-1008 \mathrm{~m}$; and ISH 3487-1979, 1: $125 \mathrm{~mm}, 36^{\circ} 24^{\prime} \mathrm{N}, 74^{\circ} 43^{\prime} \mathrm{W}, 820-800 \mathrm{~m}$ ), identified by Chernova, are new western North Atlantic records.

Paraliparis vaillanti Chernova, 2004 - Mesopelagic, 423 m over a bottom depth of $1150 \mathrm{~m}$. Known from a single specimen (MNHN 2000-5391, 1:118 $\mathrm{mm}, 46^{\circ} 39^{\prime} \mathrm{N}, 58^{\circ} 41^{\prime} \mathrm{N}$ ) taken from the Laurentian Channel (Chernova 2004). This rare, recently described species is included because it was found just outside the area.

\section{Caristiidae-Manefishes}

Paracaristius maderensis (Maul, 1949) - Epi- to bathypelagic, in subtropical waters, probably worldwide (Trunov and Kukuev 2004, Trunov et al. 2006). As noted by Moore et al. (2003), the family Caristiidae is in need of revision, and identifications are often questionable. Trunov and Kukuev (2004) described in detail a specimen $(1: 135 \mathrm{~mm})$ of this species under the name $\mathrm{Ca}$ ristius maderensis taken off Nova Scotia $\left(42^{\circ} 05^{\prime} \mathrm{N}, 63^{\circ} 35^{\prime} \mathrm{W}, 500 \mathrm{~m}, 29\right.$ April 1983) that confirms its capture in the area. Trunov et al. (2006) erected the genus Paracaristius for this and another species, P. heemstrai.

\section{Chiasmodontidae - Black swallowers}

Kali parri Johnson and Cohen, 1974 - Meso- to bathypelagic in the South and western Central Atlantic (Johnson and Cohen 1974). Two specimens

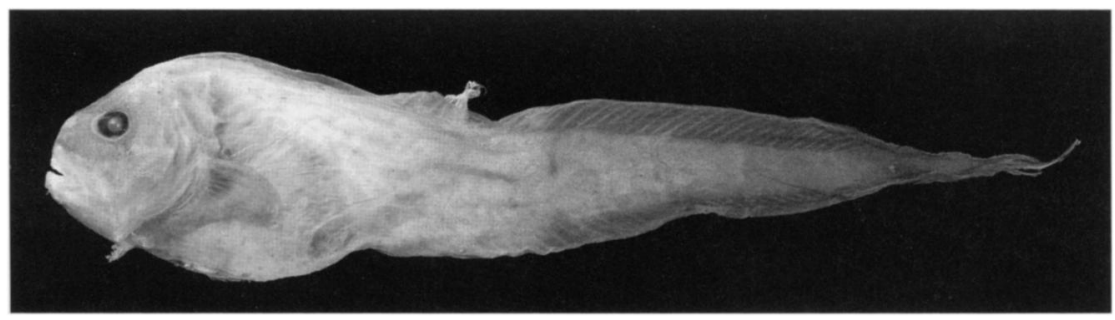

Figure 13. Paraliparis hystrix, MCZ 155473, $140 \mathrm{~mm} \mathrm{SL}, 38^{\circ} 11^{\prime} \mathrm{N}, 73^{\circ} 38^{\prime} \mathrm{W}$, $667-682 \mathrm{~m}$. 
identified as K. macrodon in Moore et al. (2003) were redetermined as K. parri by M. Melo (Auburn University Museum [AUM], Auburn, AL, pers. comm. 2006). An additional specimen ( $\mathrm{MCZ} 164284,1: 97 \mathrm{~mm}, 39^{\circ} 52^{\prime} \mathrm{N}, 67^{\circ} 21^{\prime} \mathrm{W}$, $01400 \mathrm{~m}, 5$ June 2004) collected over Bear Seamount has been tentatively identified by Melo as $K$. parri. These specimens represent the only known records of this species in the western North Atlantic.

Pseudoscopelus aphos Prokofiev and Kukuev, 2005 - Meso- to bathypelagic. Previously known from only the holotype, M. Melo identified two specimens of this recently described species while reviewing the MCZ specimens of Pseudoscopelus. One of these specimens (MCZ 68461, 1: $61 \mathrm{~mm}$, $38^{\circ} 53^{\prime} \mathrm{N}, 70^{\circ} 48^{\prime} \mathrm{W}, 340 \mathrm{~m}, 17$ August 1977 ) is from the area, and the second (MCZ 160792, 1:27 mm, 25 $56^{\prime} \mathrm{N}, 77^{\circ} 28^{\prime} \mathrm{W}, 0400$ mwo, 23 October 1984) is from south of the area.

Pseudoscopelus astronesthidens Prokofiev and Kukuev, 2005 - Meso- to bathypelagic. In the recent description of this species, Prokofiev and Kukuev (2006) reported specimens listed by Moore et al. (2003) as an undescribed species (MCZ 41443 and 68420). Additional specimens have been captured from the area (MCZ 164170; $1: 78 \mathrm{~mm}, 39^{\circ} 55^{\prime} \mathrm{N}, 67^{\circ} 19^{\prime} \mathrm{W}, 1082 \mathrm{~m}, 5$ June 2004; MCZ 164171, 1:124, 39 $55^{\prime} \mathrm{N}, 67^{\circ} 24^{\prime} \mathrm{W}, 870 \mathrm{~m}, 6$ June 2004).

\section{Tetraodontiformes}

\section{Triacanthodidae-Spikefishes}

Parahollardia lineata (Longley, 1935) (Fig. 14) - Benthic, 119-396 m, from northern Gulf of Mexico to Florida and north to Virginia (Robins et al. 1986). A specimen (MCZ 162936, 1:390 mm, 38 $22^{\prime} \mathrm{N}, 73^{\circ} 42^{\prime} \mathrm{W}, 90 \mathrm{~m}$ ) taken by the F/V Jason \& Danielle near Baltimore Canyon extends the range of the species north into the area.

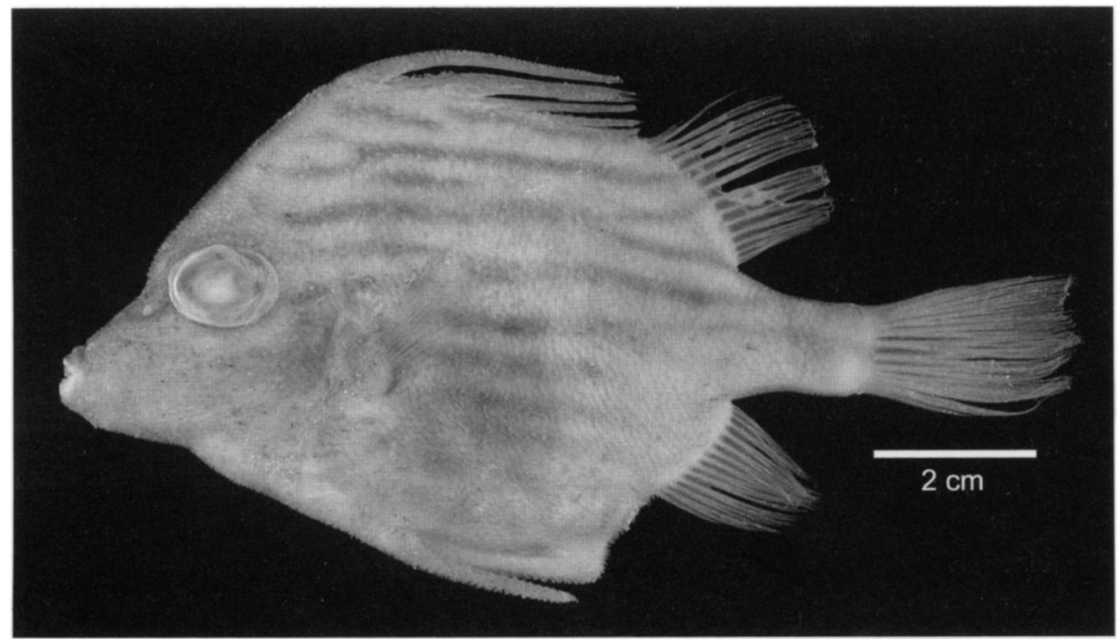

Figure 14. Parahollardia lineata, MCZ 162936, $390 \mathrm{~mm} \mathrm{SL}, 38^{\circ} 22^{\prime} \mathrm{N}, 73^{\circ} 42^{\prime} \mathrm{W}, 99 \mathrm{~m}$. 
Errata To Moore et al. (2003)

Table 1: $7^{\text {th }}$ line from bottom, "Polymixiiformes-brardfishes" should be "Polymixiiformes-beardfishes".

Page 169: MCZ 91550 is listed as a 150-mm TL Centroscymnus, but the specimen is a $1500-\mathrm{mm}$ TL specimen of Centrophorus niaukang (Anna Verissimo, Virginia Institute of Marine Science [VIMS], Gloucester Point, VA, pers. comm. 2007).

Page 192: MCZ 162258, listed under Aristostomias lunifer, was re-identified by C. Kenaley as Pachystomias microdon in a recent review of Aristostomias species held by the MCZ.

Pages 207-08: Under Spectrunculus grandis, MCZ 146882 and 146883 are in fact specimens of Barathrites parri. See page 205 for the species account.

Page 223: Liparidae is the preferred family name for the snailfishes $(\mathrm{N}$. Chernova, ZIN, St. Petersburg, Russia, pers. comm. 2005); the family Liparidae was formerly lumped with the family Cyclopteridae.

Page 224: Synagrops bellus is inseparable from its senior synonym S. japonicus (Döderlein in Steindachner and Döderlein), and Howella brodiei is now considered H. atlantica Post and Quéro (P.C. Heemstra, unpubl. data)

Page 225: MCZ 150975 listed as Symphysanodon berryi is in fact a postlarval Epigonus sp. (Anderson and Springer 2005).

\section{Acknowledgments}

M. Vecchione (NMFS) organized, sought, and received funding for the exploratory trawling by the RV Delaware II; we thank him for access to this material. Our thanks to A. Holmes (formerly MCZ now ANSP) and A. Williston (MCZ) for curatorial support and for taking several images. E. Shea assisted with data management. D. Markle (OS), M. Melo (AUM), J. Nielsen (ZMUC), J. Paxton (AMS), T. Pietsch (UW), and D. Smith (USNM) identified several specimens or otherwise confirmed our identifications. C.P. Kenaley was supported in part by the Dorothy T. Gilbert Memorial Endowment at the University of Washington and National Science Foundation Grant DEB-0314637, T.W. Pietsch, principal investigator.

\section{Literature Cited}

Anderson, W.D., and V.G. Springer. 2005. Review of the perciform fish genus Symphysanodon Bleeker (Symphysanodontidae), with descriptions of three new species, S. mona, S. parini, and S. rhax. Zootaxa 996:1-44.

Bertelsen, E. 1980. Notes on Linophrynidae V: A revision of the deepsea anglerfishes of the Linophryne arborifer-group (Pisces, Ceratioidei). Steenstrupia 6(6): 29-70.

Bertelsen, E. 1982. Notes on Linophrynidae VIII: A review of the genus Linophryne, with new records and descriptions of two new species. Steenstrupia 8(3): 49-104. 
Bertelsen, E., and D.B. Grobecker. 1980. A new species of the ceratioid anglerfish genus Oneirodes (Pisces: Lophiiformes) from the eastern North Atlantic. Archiv für Fischereiwissenschaft 31(2):63-66.

Bertelsen, E., and G. Krefft. 1988. The ceratioid family Himantolophidae (Pisces, Lophiiformes). Steenstrupia 14(2):9-89.

Bertelsen, E., and J. Nielsen. 1987. The deep sea eel family Monognathidae (Pisces, Anguilliformes). Steenstrupia 13:141-198.

Bertelsen, E., T.W. Pietsch, and R.J. Lavenberg. 1981. Ceratioid anglerfishes of the family Gigantactinidae: Morphology, systematics, and distribution. Natural History Museum of L.A. County, Contributions to Science 332:vi $+74 \mathrm{pp}$.

Castle, P.H.J. 1967. Two remarkable eel-larvae from off Southern Africa. J.L.B. Smith Institute for Ichthyology Special Publication No. 1:1-12, pls. 11-12.

Castle, P.H.J. 1978. Results of the research cruises of FRV "Walther Herwig" to South America. L. A new genus and species of bobtail eel (Anguilliformes, Cyemidae) from the South Atlantic. Archiv für Fishereiwissenchaft 28(2-3):69-76.

Chernova, N.V. 2004. A new species of snailfishes (Liparidae) Paraliparis vaillanti sp. nova from the northwestern Atlantic, with the redescription of a rare species Paraliparis edwardsi Vaillant. Voprosy Ikhtiologii 44(2):149-153. [In Russian. English translation in Journal of Ichthyology 44(2):135-139].

Clarke, T.A. 2000. Review of nine species of North Atlantic Eustomias, subgenus Dinematochirus (Pisces: Stomiidae), with the description of two new species. Copeia 2000(1):96-111.

Cohen, D.M. 1984. Opisthoproctidae. Pp. 395-398, In Whitehead, P.J. P., M.-L. Bauchot, J.-C. Hureau, J. Nielsen, and E. Tortonese (Eds.). Fishes of the Northeastern Atlantic and Mediterranean. Unesco, Paris, France. 1473 pp.

Cohen, D.M., T. Indada, T. Iwamoto, and N. Scialabba. 1990. FAO species catalogue. Volume 10. Gadiform fishes of the world (order Gadiformes). An annotated and illustrated catalogue of cods, hakes, grenadiers and other gadiform fishes known to date. FAO Fisheries Synopsis 125(10):1-442.

Gibbs, R.H., Jr. 1984. Astronesthidae. Pp. 325-335, In P.J.P. Whitehead, M.-L. Bauchot, J.-C. Hureau, J. Nielsen, and E. Tortonese (Eds.). Fishes of the Northeastern Atlantic and the Mediterranean. UNESCO, Paris. 1473 pp.

Gibbs, R.H., Jr., and M.A. Barnett. 1990. Melanostomiidae. Pp. 308-337, In J.C. Quéro, J.C. Hureau, C. Karrer, A. Post, and L. Saldanha (Eds.). Check-list of the Fishes of the Eastern Tropical Atlantic (CLOFETA). UNESCO, Paris, France. $1492 \mathrm{pp}$.

Gomon, J.R., and R.H. Gibbs, Jr. 1985. Taxonomy and distribution of the stomioid fish genus Eustomias (Melanostomiidae), II: Biradiostomias, new subgenus. Smithsonian Contributions to Zoology No. 409:1-58.

Iglésias, S.P., K. Nakaya, and M. Stehmann. 2004. Apristurus melanoasper, a new species of deep-water catshark from the North Atlantic (Chondrichthyes: Carcharhiniformes: Scyliorhinidae). Cybium 28:345-356.

Johnson, R.K. 1974. A revision of the alepisauroid family Scopelarchidae (Pisces: Myctophiformes). Fieldiana Zoology 66:i-ix + 1-249 pp.

Johnson, R.K., and E. Bertelsen. 1991. The fishes of the family Giganturidae: systematics, distribution and aspects of biology. Dana Report 91:1-45.

Johnson, R.K., and D.M. Cohen. 1974. Results of the research cruises of FRV "Walther Herwig" to South America. XXX. Revision of the chiasmodontid fish genera Dysalotus and Kali, with descriptions of two new species. Archiv für Fischereiwissenschaft 25(1/2):13-46. 
Kenaley, C.P. In Press. Diel vertical migration of the loosejaw dragonfishes (Stomiiformes: Stomiidae: Malacosteinae): A new analysis for rare pelagic taxa. Journal of Fish Biology.

Kenaley, C.P., and K.E. Hartel. 2005. A revision of Atlantic species of Photostomias (Teleostei: Stomiidae: Malacosteinae), with a description of a new species. Ichthyological Research 52(3):251-263.

Leviton, A.E., R.H. Gibbs, Jr., E. Heal, and C.E. Dawson. 1985. Standards in herpetology and ichthyology: Part I. Standard symbolic codes for institutional resource collections in herpetology and ichthyology. Copeia 1985:802-832.

Markle, D.F., and Y.I. Sazonov. 1990. Alepocephalidae. Pp. 246-264, In J.C. Quero, J.C. Hureau, C. Karrer, A. Post, and L. Saldanha (Eds.). Check-list of the Fishes of the Eastern Tropical Atlantic (CLOFETA). UNESCO, Paris, France. 1492 pp.

McEachran, J.D., and J.D. Fechhelm. 1998. Fishes of the Gulf of Mexico. University of Texas Press, Austin, TX. i-viii, 1-1112 pp.

Moore, J.A., K.E. Hartel, J.E. Craddock, and J.K. Galbraith. 2003. An annotated list of deepwater fishes from off the New England region, with new area records. Northeastern Naturalist 10(2):159-248.

Morrow, J.E., Jr., and R.H. Gibbs, Jr. 1964. Melanostomiatidae. Fishes of the Western North Atlantic. Memoir of the Sears Foundation for Marine Research 1(4): 351-522.

Nielsen, J.G., D.M. Cohen, D.F. Markle, and C.R. Robins. 1999. FAO species catalogue. Volume 18. Ophidiiform fishes of the world (Order Ophidiiformes). An annotated and illustrated catalogue of pearlfishes, cusk-eels, brotulas, and other ophidiiform fishes known to date. FAO Fisheries Synopsis 125:1-178.

Pakhorukov, N.P. 1999. Observations of deep-sea fishes from submersibles in the Sierra Leone Rise area (Atlantic Ocean). Voprosy Ikhtiologii 39(5):653-660. [In Russian. English translation in Journal of Ichthyology 39(8):626-633].

Parin, N.V., and O.D. Borodulina. 2002. Preliminary review of Astronesthes niger species group (Astronesthidae, Stomiiformes) with description of six new species from the Atlantic and Indian Oceans. Voprosy Ikhtiologii 42(4):437-458. [In Russian. English translation in Journal of Ichthyology 42(7):495-515].

Paxton, J.R. 1989. Synopsis of the whalefishes (family Cetomimidae) with descriptions of four new genera. Records of the Australian Museum 41:135-206.

Pietsch, T.W. 1972. Ergebnisse der Forschungsreisen des FFS "Walther Herwig" nach Südamerika. XIX. Systematics and distribution of ceratioid fishes of the genus Dolopichthys (family Oneirodidae), with the description of a new species. Archiv für Fischereiwissenschaft 23(1):1-28.

Pietsch, T.W. 2004. Revision of the deep-sea anglerfish genus Phyllorhinichthys Pietsch (Lophiiformes: Ceratioidei: Oneirodidae), with the description of a new species from the Atlantic Ocean. Copeia 2004(4):797-803.

Prokofiev, A.M., and E.I. Kukuev. 2006. Two new species of linebellies (genus Pseudoscopelus) with a revised key of species (Perciformes: Chiasmodontidae). Voprosy Ikhtiologii 46(4):558-561. [In Russian. English translation in Journal of Ichthyology 46(4):481-484].

Quero, J.C., T. Matsui, R.H. Rosenblatt, and Y.I. Sazonov. 1990. Platytroctidae. Pp. 265-274, In J.C. Quero, J.C. Hureau, C. Karrer, A. Post, and L. Saldanha (Eds.). Check-list of the Fishes of the Eastern Tropical Atlantic (CLOFETA). UNESCO, Paris, France. 1492 pp. 
Robins, C.R., G.C. Ray, and J. Douglas. 1986. A Field Guide to Atlantic Coast Fishes of North America. Houghton Mifflin Boston, MA. 354 pp.

Smith, D.G. 1989a. Congridae. Fishes of the Western North Atlantic. Memoir of the Sears Foundation for Marine Research 1(9):460-567.

Smith, D.G. 1989b. Cyematidae. Fishes of the Western North Atlantic. Memoir of the Sears Foundation for Marine Research 1 (9):630-635.

Sulak, K.J. 1990. Halosauridae. Pp. 126-132, In J.C. Quero, J.C. Hureau, C. Karrer, A. Post, and L. Saldanha (Eds.). Check-list of the Fishes of the Eastern Tropical Atlantic (CLOFETA). UNESCO, Paris, France. 1492 pp.

Sutton, T.T., and K.E. Hartel. 2004. New species of Eustomias (Teleostei: Stomiidae) from the western North Atlantic, with a review of the subgenus Neostomias. Copeia 2004(1):116-121.

Trunov, I.A., and E.I. Kukuev. 2004. The first landing of Caristius maderensis (Caristiidae) in Nova Scotia (Northwestern Atlantic). Voprosy Ikhtiologii 44(2):170171. [In Russian. English translation in Journal of Ichthyology 44(2):180-181].

Trunov, I.A., E.I. Kukuev, and N.V. Parin. 2006. Materials for the revision of the family Caristiidae (Perciformes): 1. Description of Paracaristius heemstrai gen. et sp. nov. Voprosy Ikhtiologii 46(4):465-470. [In Russian. English translation in Journal of Ichthyology 46(6):441-446]. 